\title{
Piperlongumine and some of its analogs inhibit selectively the human immunoproteasome over the constitutive proteasome
}

\author{
Elodie Bosc ${ }^{\text {a, }}$, Jhennifer Nastri ${ }^{\text {b, }}{ }^{1}$, Valérie Lefort ${ }^{\text {a }}$, Marilia Valli ${ }^{\mathrm{b}}$, Fernando Contiguiba ${ }^{\mathrm{c}}$, \\ Renan Pioli ${ }^{\mathrm{d}}$, Maysa Furlan ${ }^{\mathrm{b}}$, Vanderlan da Silva Bolzani ${ }^{\mathrm{b}}$, Chahrazade El Amri ${ }^{\mathrm{a},{ }^{* *} \text {, }}$ \\ Michèle Reboud-Ravaux ${ }^{\mathrm{a},{ }^{*}}$ \\ a Sorbonne Université, UPMC Univ Paris 06-CNRS, IBPS, UMR 8256, Inserm ERL1164, B2A, 7 Quai Saint Bernard, F75005 Paris, France \\ ${ }^{\mathrm{b}}$ Nuclei of Bioassays, Biosynthesis and Ecophysiology of Natural Products (NuBBE), Department of Organic Chemistry, Institute of Chemistry, Sao Paulo \\ State University - UNESP, 14800-060, Araraquara, SP, Brazil \\ ${ }^{\mathrm{c}}$ Institute for Natural Products Research Walter Mors, Health Sciences Center - HSC, Federal University of Rio de Janeiro - UFRJ, 21941902, Rio de Janeiro, RJ, \\ Brazil \\ ${ }^{\mathrm{d}}$ Institute of Chemistry, Department of Organic Chemistry, University of São Paulo - USP, 05508-000, São Paulo, SP, Brazil
}

\section{A R T I C L E I N F O}

\section{Article history:}

Received 8 January 2018

Accepted 15 January 2018

\section{Keywords:}

Piperlogumine

Piperlongumine analogs

Proteasome

Immunoproteasome

\begin{abstract}
A B S T R A C T
The natural small molecule piperlongumine A is toxic selectively to cancer cells in vitro and in vivo. This toxicity has been correlated with cancer cell ROS, DNA damage and apoptotic cell death increases. We demonstrate here a new mechanistic property of piperlongumine: it inhibits selectively human immunoproteasome with no noticeable inhibition of human constitutive proteasome. This result suggests that immunoproteasome inhibition, a mechanism independent of ROS elevation, may also partly play a role in the anticancer effects observed with piperlongumine. Structure-activity relationships of piperlongumine analogs suggest that the lactam (piperidonic) ring of piperlongumine A may be replaced by the linear olefin $-\mathrm{NHCO}-\mathrm{CH}_{2}=\mathrm{CH}_{2}$ to improve both in vitro inhibitory efficiency against immunoproteasome and cellular toxicity.
\end{abstract}

๑) 2018 Elsevier Inc. All rights reserved.

\section{Introduction}

Piperlongumine $\mathrm{A}(\mathrm{PL})$ is an alkaloid isolated from some vegetal species of Piper (Piperaceae) (Fig. 1A). Several PL biological effects have been reported such as cytotoxic, genotoxic, anti-angiogenic, anti-metastatic and anti-tumor activities [1]. The natural PL molecule induces apoptosis in osteosarcoma, breast, bladder and lung cancer cells, but importantly not in normal cells [2]. A potent inhibition of breast cancer cell line migration was observed with PL analogs [3]. PL increases reactive oxygen species (ROS) and apoptotic cell death in both cancer cells and normal cells engineered to have a cancer genotype, irrespective of p53 status, with little effect in primary normal cells [4]. Using a panel of PL analogs, Adams et al. analyzed the mechanism of action of PL and suggested

\footnotetext{
* Corresponding author.

** Corresponding author.

E-mail addresses: chahrazade.el_amri@upmc.fr (C. El Amri), michele.reboud@ upmc.fr (M. Reboud-Ravaux).

1 These authors contributed equally to this work.
}

that ROS-independent mechanisms, including cross-linking events, may also contribute to PL's induction of apoptosis [5]. An inhibition of the ubiquitin-proteasome system by PL was then reported by Jarvius et al. [6] but no inhibition of the 20S proteasome itself, or of $19 S$ deubiquitinating activity was observed at concentrations inducing cytotoxicity. These observations motivated us to investigate the potential interaction between PL and proteasome. Indeed, the proteasome is now a valuable anticancer drug target [7]. This highly complex protease is formed of a $20 \mathrm{~S}$ catalytic core particle (CP) complexed with regulatory particles such as $19 \mathrm{~S}$ for constitutive proteasome or $11 \mathrm{~S}$ for inducible immunoproteasome $[8,9]$. The CPs of both proteasomes are composed of four stacked heptameric rings with two outer rings ( $\alpha 1-7)$ formed by the $\alpha$ subunits and two inner rings formed of $\beta$ subunits ( $\beta 1-7)$. The two $\beta 1 \mathrm{c}$, two $\beta 2 \mathrm{c}$ and two $\beta 5$ c catalytic units of the constitutive $\mathrm{cCP}$ are each replaced by the $\beta 1 \mathrm{i}, \beta 2 \mathrm{i}$ and $\beta 3 \mathrm{i}$ subunits in inducible iCP. They bear caspase-like or post-acid activity (PA) for $\beta 1$, trypsin-like activity (T-L) for $\beta 2$ and chymotrypsin-like activity (ChT-L) for $\beta 5$ subunits. Considerable efforts to develop proteasome inhibitors $[7,8]$ have been made leading to noncovalent inhibitors [10-13] or covalent ones such as 
<smiles>COc1cc(/C=C/C(=O)N2CCCCC2=O)cc(OC)c1OC</smiles>

1

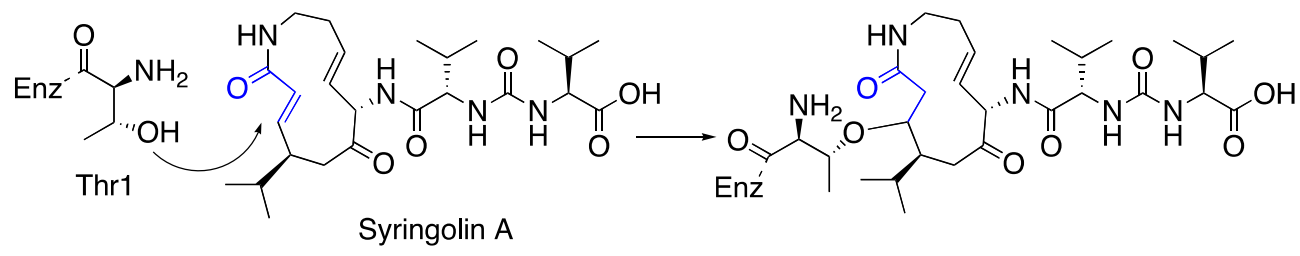

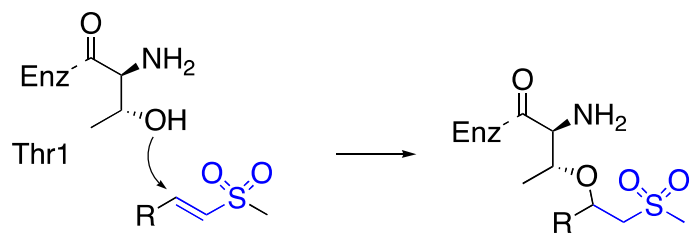

Vinyl sulfone<smiles>COc1cc(/C=C/C=O)cc(OC)c1OC</smiles><smiles>CN1CCC=CC1=O</smiles>

1<smiles>CN1C(=O)C=CC1=O</smiles>

2<smiles>CN1C(=O)c2ccccc2C1=O</smiles>

3<smiles>C=CC(=O)NC</smiles>

4

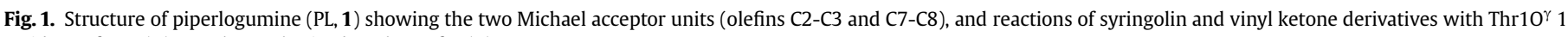
residues of $\mathrm{CCP}(\mathrm{A})$. Newly synthesized analogs of $\mathbf{1}(\mathrm{B})$.

the three approved drugs used in the treatment of hematologic malignancies, bortezomib (Velcade ${ }^{\circledR}$ ) [14], carfilzomib $\left(\right.$ Kyprolis $^{\mathbb{B}}$ ) [15] and the orally administered ixazomib (Ninlaro ${ }^{\circledR}$ ) [16]. These drugs inhibit mainly the $\beta 5$ activity of the catalytic core of the cCP but also that of the iCP by creating covalent bonds with the catalytic Thr1. When considering the chemical structure of PL (1, Fig. 1A), it appears that its non-symmetric di-vinyl imide functions implicating the double bonds $\mathrm{C} 2-\mathrm{C} 3$ and $\mathrm{C} 7-\mathrm{C} 8$ (Fig. 1A) may lead to two possibilities of Michael addition with the $\mathrm{N}$-terminal nucleophilic residue $\mathrm{Thr}^{\gamma} \mathrm{O}^{\gamma}$ present in all catalytic subunits of CPs. Inhibitors displaying the parent amide vinyl group such as the natural syringolin A are known to react with $\mathrm{CCP}$ Thr $10^{\gamma}$ to give Michael adduct (Fig. 1A) [17]. The same mechanism was observed with synthetic vinyl ketones [18]. Nevertheless, Jarvius et al. found that PL did not inhibit 20S proteasome (presumably constitutive proteasome) [6]. In the other hand, the interference of $\mathrm{N}$-acetyl-Lcysteine with PL suggested that PL displays proteasome inhibitory properties [19]. In this paper, we re-examine the interaction of PL with proteasome by analyzing the inhibitory effect of PL and three of its newly synthesized analogs [3] (Fig. 1B) not only on human cCP but also human iCP. Immunoproteasome has been associated to progression of certain types of cancer, autoimmune disorders and inflammation [20]. Previous studies indicated that the 3,4,5trimethoxy cinnamic moiety of $\mathbf{1}$ does not affect its antitumor property and the $\mathrm{C} 7-\mathrm{C} 8$ site has a lesser electrophiliciy than the $\mathrm{C} 2$ C3 one [5]. We thus examined the effect of ring isomerism by replacing the PL $\delta$-valerolactam cyclic ring by the known nucleophile trap succinimide (compound $\mathbf{2}$ ) or by a non-reactive more expanded bicycle (compound 3) whereas the pharmacophore involving the C7-C8 olefin was conserved. Compound 4 showed a molecular simplification with the conserved Michael acceptor C7$\mathrm{C} 8$ and double bond $\mathrm{C} 2-\mathrm{C} 3$, but the lactam (piperidonic) ring was removed and replaced by a linear vinyl keto group [3]. We demonstrated that the human $\mathrm{CCP}$ is poorly inhibited by the tested compounds whereas iCP is efficiently inhibited by $\mathbf{1}$ and two of its analogs. The mechanism by which the iCP was inhibited by the tested compounds was determined and their potential as cytotoxic tumor reagents was evaluated. 


\section{Materials and methods}

\subsection{Inhibitors}

The isolation of PL $\mathbf{1}$ and the synthesis of compounds $\mathbf{2}-\mathbf{4}$ are described in Ref. [3].

\subsection{Enzyme activity and inhibition assays}

Purified human constitutive 20S proteasome cCP and human $20 \mathrm{~S}$ immunoproteasome iCP from erythrocytes was obtained from Boston Biochem (Cambridge, USA). The fluorogenic substrates SucLLVY-AMC and Z-LLE-AMC (AMC = 7-amino-4-methylcoumarin) were obtained from Bachem (Weil am Rhein, Germany). Other reagents and solvents were purchased from commercial sources. Fluorescence was measured using a BMG Fluostar microplate reader (black 96-well microplates).

Proteasome activities were determined by monitoring for $45 \mathrm{~min}$ at $37^{\circ} \mathrm{C}$ the hydrolysis of the appropriate fluorogenic substrate Suc-LLVY-AMC (ChT-L activity) and Z-LLE-AMC (PA activity) using $\lambda_{\mathrm{exc}}=360 \mathrm{~nm}, \lambda_{\mathrm{em}}=460 \mathrm{~nm}$ for both substrates, in the presence of untreated (control) or treated proteasome (iCP or cCP). Substrate and compounds were previously dissolved in DMSO. The buffered reaction mixtures $(\mathrm{pH} 8.0$ ) for both activities contain $20 \mathrm{mM}$ Tris, $10 \%$ (v/v) glycerol, $0.01 \%$ (w/v) SDS, and 2\% (v/v) DMSO. The final iPR and cPR concentrations were $0.6 \mathrm{nM}$ for ChT-L and PA activities using $20 \mu \mathrm{M}$ Suc-LLVY-AMC (ChT-L) and $50 \mu \mathrm{M}$ Z-LLEAMC (PA). Using the appropriate substrate, the compounds $(0.1-100 \mu \mathrm{M})$ were tested in duplicate for each inhibitor concentration to detect their potential to inhibit the ChT-L and PA activities. The enzyme and the inhibitors were incubated for $20 \mathrm{~min}$ before the measurement of the enzyme activity. Initial rates determined in control experiments $\left(\mathrm{V}_{0}\right)$ were considered to be $100 \%$ of the peptidase activity; initial rates below $100 \%$ were considered to be inhibitions. The inhibitory activity of compounds was expressed as $\mathrm{IC}_{50}$ (inhibitor concentrations giving $50 \%$ inhibition). The values of $\mathrm{IC}_{50}$ were calculated by fitting the experimental data to equation (1):

$\%$ Inhibition $=\left(100[\mathrm{I}]_{0}\right) /\left(\mathrm{IC}_{50}+[\mathrm{I}]_{0}\right)$

The reversible or irreversible character was analyzed by diluting by a factor of 100 the reaction mixtures. For the reversible inhibitor 2, a Dixon plot was used: $[2]=2.56-100 \mu \mathrm{M},[\mathrm{iCP}]_{0}=0.6 \mathrm{nM}$, $[S]_{0}=10-80 \mu \mathrm{M}$. For the irreversible compounds 1 and 4 , the timedependence of the inhibition was followed by determining the remaining activity percentage at various incubation times $\left([\mathrm{iCP}]_{0}=60 \mathrm{nM}\right)$. The pseudo first-order inactivation rate constants were obtained from plots of $\ln (\%$ remaining activity) vs preincubation time, and expressed in terms of the apparent secondorder inactivation rate constants $\mathrm{k}_{\mathrm{obs}} /[\mathrm{I}]_{0} \mathrm{M}^{-1} \mathrm{~s}^{-1}$. The Kaleidagraph software was used for data analysis.

\subsection{Cytotoxicity assays}

Assays were performed on the human cancer cell line HeLa (human cervical carcinoma) obtained from ATTC. The cells were grown in DMEM (Dulbecco's Modified Eagle Medium; Sigma) supplemented with $10 \%$ fetal bovine serum in a $5 \% \mathrm{CO}_{2}$ humidified atmosphere. Confluent cells were collected and then preincubated without inhibitor for $24 \mathrm{~h}$. They were then treated during $48 \mathrm{~h}$ using increasing concentrations of compounds: $10 \mathrm{nM}-50 \mu \mathrm{M}$ with a final DMSO concentration of $0.02 \%(\mathrm{v} / \mathrm{v})$. After removal of the DMEM medium, a XTT salt solution was added for $3 \mathrm{~h}$ to each well (100 $\mu \mathrm{L}$ at $0.3 \mathrm{mg} / \mathrm{mL}$ containing $8.3 \mathrm{mM}$ PBS) (XTT, 2,3-bis-(2-
methoxy-4-nitro-5-sulfophenyl)-2H-tetrazolium-5-carboxanilide; Cell Proliferation kit 11465015001 Roche). Absorbance at $485 \mathrm{~nm}$ was measured using a BMG Fluostar microplate reader. The cytotoxicity activity was expressed as the concentration inhibiting cell growth by $50 \%\left(E_{50}\right)$ calculated from the survival curves. The experimental data were fitted to the following equation where $E$ is the survival percentage, $C$ the drug concentration, $E_{\max }$ the maximum drug effect, and $n$ the Hill constant, which describes the shape of the curve:

$E=100-\left(E_{\max } \times C^{n}\right) /\left(C^{n}+E C_{50}^{n}\right)$

The Kaleidagraph software was used for data analysis.

\section{Results and discussion}

\subsection{Screening of PL and its analogs on $c C p$ and $i C P$ activities}

We evaluated the capacity of compound $\mathbf{1}$ and its analogs to inhibit the ChT-L and PA activities of human CCP and iCP. Both ChT-L and PA activities of cCP were not or very poorly inhibited (less than $20 \%$ at $10 \mu \mathrm{M}$ and $30 \%$ at $50 \mu \mathrm{M}$ ). Conversely, a noticeable inhibition of the ChT-L activity of iCP was observed for compounds 1, 2 and 4, and the corresponding $\mathrm{IC}_{50}$ values (concentration of inhibitor leading to 50\% inhibition) were determined (Fig. 2 and Table 1). The replacement of the monocyclic $\delta$-valerolactam $\mathrm{R}$ group in $\mathbf{1}$ $\left(\mathrm{IC}_{50}=15.0 \pm 1.1 \mu \mathrm{M}\right)$ by the pentacyclic succimidyl in $\mathbf{2}$ was well tolerated ( $\mathrm{IC}_{50}$ of $12.7 \pm 1.1 \mu \mathrm{M}$ ). The larger bicyclic group in 3 devoid of an electrophilic group abolished the inhibitory activity besides the presence of C7-C8 olefin. Conversely, the simplified $\mathrm{R}$ group that retained the aliphatic $-\mathrm{NHCO}-\mathrm{CH}_{2}=\mathrm{CH}_{2}$ motif increased the inhibitory potency by a factor of 5.8. This higher efficiency of 4 on iCP corroborates its higher efficiency against MDA-MB-231 breast cancer cell migration analyzed using the Boyden chamber assay ( $\mathrm{EC}_{50}$ of $1.5 \pm 1 \mu \mathrm{M}$ for 4 and of $3.0 \pm 1.0 \mu \mathrm{M}$ for $\mathbf{1}$ ) [3]. These results highlight the favorable role to inhibit $\mathrm{iCP}$ of the smaller aliphatic $-\mathrm{NHCO}-\mathrm{CH}_{2}=\mathrm{CH}_{2}$ group compared to the lactam piperidonic ring in 1. The absence of an electrophilic function at $\mathrm{C2}-\mathrm{C} 3$ as in compound 3 seems unfavorable for such an inhibition. It failed also to inhibit cell migration at $10 \mu \mathrm{M}$ in the wound healing MDAMB-231 cells assay. The need of both Michael acceptors C2-C3 and C7-C8 to observe potent cell death was also reported [5].

\subsection{Mechanistic studies}

The reversible or irreversible character of the inhibition towards the ChT-L activity of iCP by compounds 1,2 and 4 was analyzed. After reaction with compounds $\mathbf{2}$ and $\mathbf{4}$, no enzyme reactivation was observed after dilution (factor of 100). This was in agreement with an irreversible process. Conversely, the activity was recovered after a previous treatment of iCP with compound $\mathbf{2}$. Moreover, for this compound, increasing amounts of the ChT-L activity fluorogenic substrate reversed the inhibition process. The Dixon plot (Fig. 3A) demonstrated that compound $\mathbf{2}$ acted as a competitive inhibitor binding only to free enzyme with $\mathrm{K}_{\mathrm{i}}=38.9 \pm 3.8 \mu \mathrm{M}$. Conversely, a time-dependent inhibition was observed for compounds 1 and 4, and a pseudo-first process was followed during $60 \%$ of the inactivation process. The apparent second-order inactivation rate constants $k_{o b s} /[I]_{0}$ were of $36 \pm 2 \mathrm{M}^{-1} \mathrm{~s}^{-1}$ for $\mathbf{1}$ and $170 \pm 10 \mathrm{M}^{-1} \mathrm{~s}^{-1}$ for 4 . The inactivation efficacy was increased by a factor of 4.7 for $\mathbf{4}$ compared to $\mathbf{1}$. Due to the irreversible character of the inhibition, these inactivation indexes may lead to noticeable inhibitions (for example, 97\% inhibition after 30 min treatment at $10 \mu \mathrm{M}$ for 4 ). 

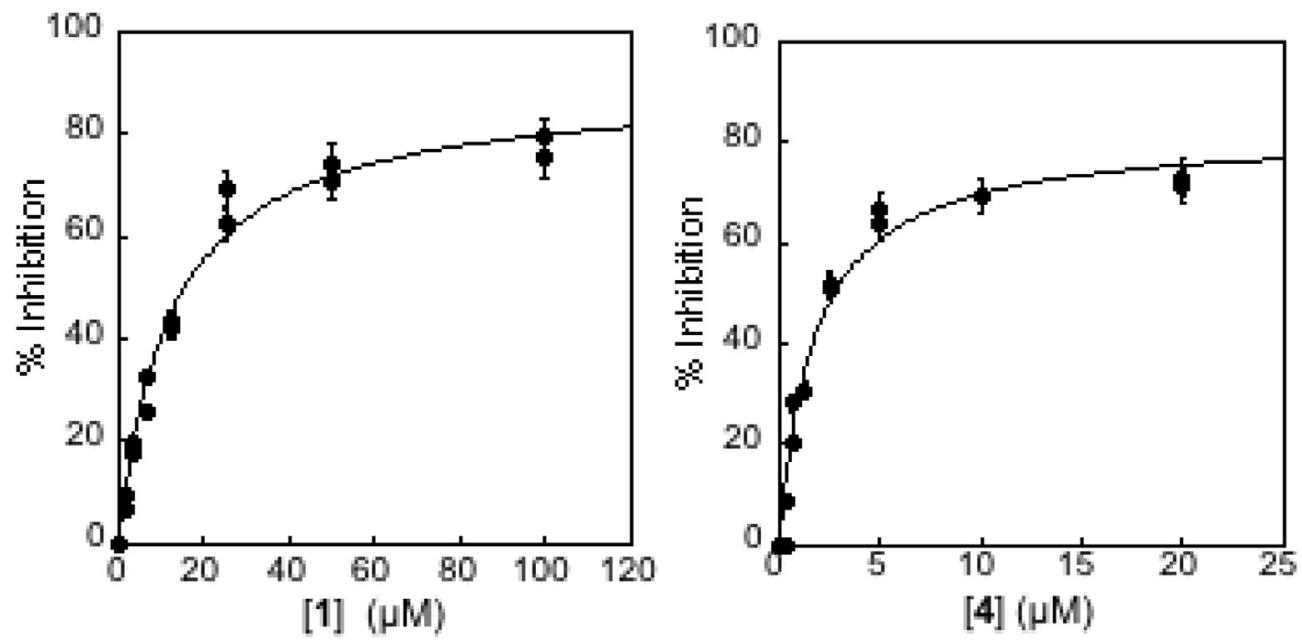

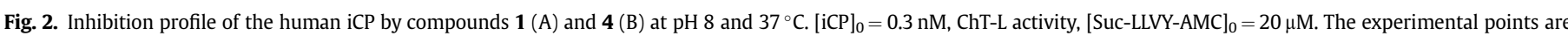
adjusted to equation (1).

Table 1

Biological activities of compounds 1-4.

\begin{tabular}{|c|c|c|c|c|}
\hline \multirow[t]{3}{*}{ Compounds } & \multicolumn{3}{|c|}{$\begin{array}{l}\text { Enzyme assays }^{\mathrm{a}} \\
\mathrm{IC}_{50}{ }^{\mathrm{b}}(\mu \mathrm{M})\end{array}$} & \multirow[t]{3}{*}{$\begin{array}{l}\text { Cell assays } \\
\mathrm{EC}_{50}{ }^{\mathrm{d}}(\mu \mathrm{M})\end{array}$} \\
\hline & \multicolumn{2}{|c|}{ ChT-L activity } & \multirow{2}{*}{$\frac{\text { PA activity }}{\mathrm{CCP}}$} & \\
\hline & $\mathrm{cCP}$ & $\mathrm{iCP}$ & & \\
\hline 1 & ni & $15.0 \pm 1.1$ & $\mathrm{ni}$ & $2.7 \pm 0.1$ \\
\hline 2 & ni & $12.7 \pm 1.1$ & ni & nt \\
\hline 3 & ni & ni & ni & nt \\
\hline 4 & ni & $2.6 \pm 0.3$ & ni & $14.0 \pm 1$ \\
\hline
\end{tabular}

a The inhibition of the human $\mathrm{cCP}$ and iCP at $\mathrm{pH} 8$ and $37^{\circ} \mathrm{C}$ was evaluated after 20 min incubation of the enzyme with the respective compound before adding the appropriate substrate (Suc-LLVY-AMC for ChT-L activity and Z-LLE-AMC for PA activity).

$\mathrm{b}$ The $\mathrm{IC}_{50}$ values were calculated by fitting the experimental data to eq. (1). ni, inhibition $<30 \%$ at $50 \mu \mathrm{M}$.

c The cytotoxic activity was evaluated against HeLa cells after incubation for $48 \mathrm{~h}$ and using the XXT assay. Values in bar graphs are mean $\pm \mathrm{sd}$ (experiments in triplicate). nt indicates no loss of viability at $50 \mu \mathrm{M}$.

d ${ }^{2}$ The $\mathrm{IC}_{50}$ values were calculated by fitting the experimental data to eq. 2 .

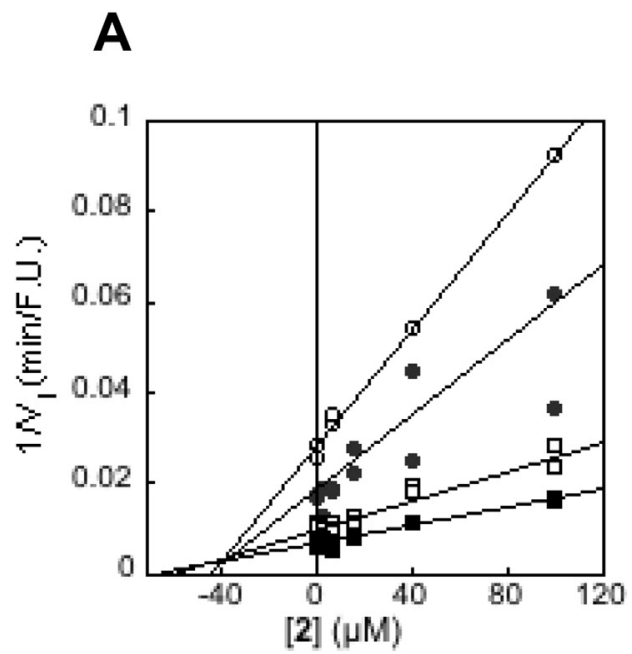

\section{B}

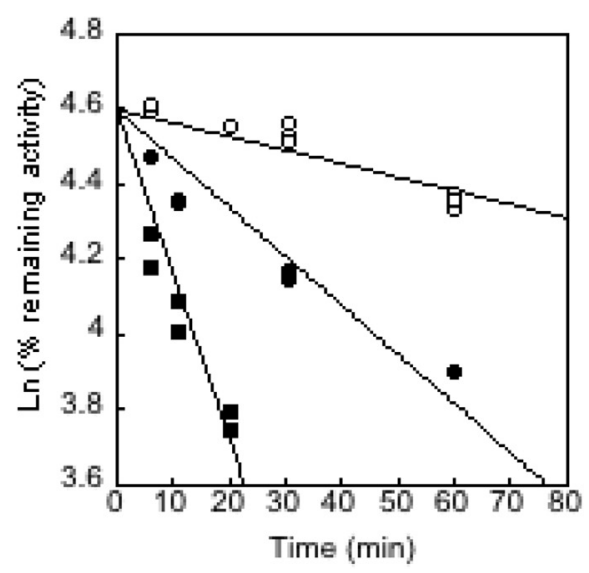

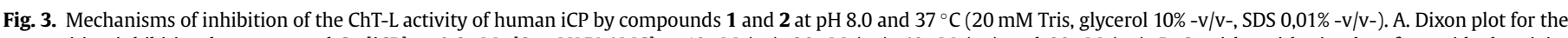

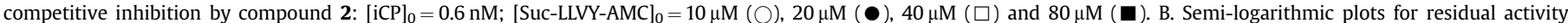
measured at various intervals for increasing compound $\mathbf{1}$ concentrations as a function of preincubation time: $[\mathrm{iCP}]_{0}=60 \mathrm{nM} ;[\mathbf{1}]=0(\bigcirc), 4 \mu \mathrm{M}(\mathbf{0})$ and $20 \mu \mathrm{M}(\mathbf{0})$ 
A

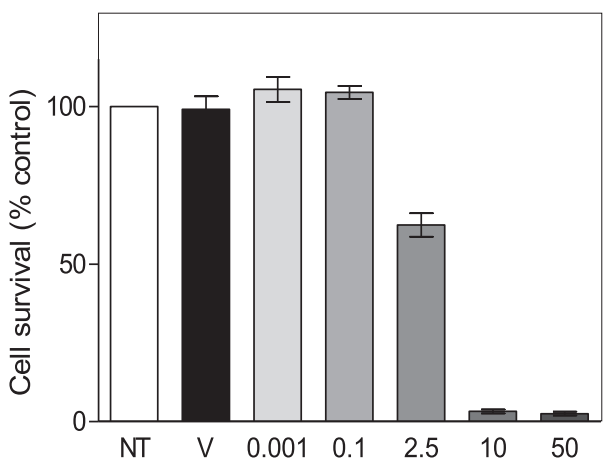

[1] $(\mu \mathrm{M})$
B

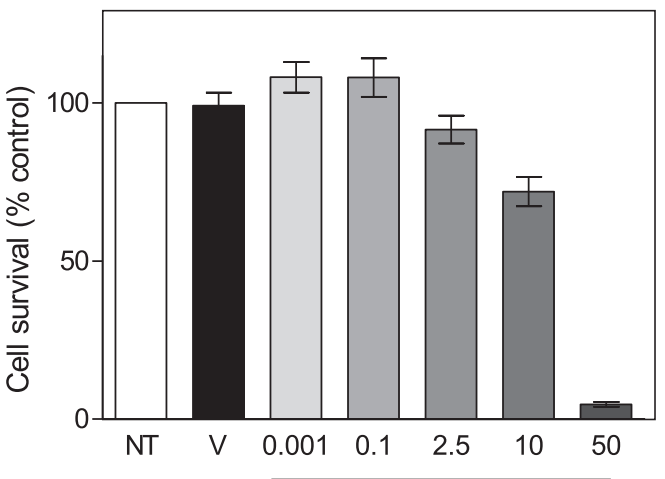

[4] $(\mu \mathrm{M})$

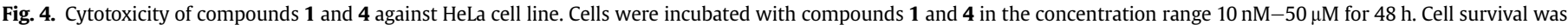
then measured using MTT assay.

\subsection{Cellular toxicity}

It is known that many proteasome inhibitors are toxic against HeLa cells and several tumor cell lines [7,12]. The cytotoxic effect of compounds 1-4 was evaluated on human cancer cell line HeLa (cervix) using the XTT assay. Compounds $\mathbf{2}$ and $\mathbf{3}$ were devoid of any cytotoxic effect even at $50 \mu \mathrm{M}$ (Table 1 ). Survival curves yielded $\mathrm{EC}_{50}$ values of $2.7 \pm 0.1 \mu \mathrm{M}$ for 1 and $14.0 \pm 1 \mu \mathrm{M}$ for 4 (Fig. 4 , Table 1). This result was expected for compound 1 since it has been identified to be toxic selectively to cancer cells in vitro and in vivo with the $\mathrm{EC}_{50}$ value of $7.1 \mu \mathrm{M}$ against HeLa cells [5]. The compound 1 antitumor efficacy was correlated with a cancer selective increase in markers of oxidative stress such as ROS, and also with DNA damage and apoptotic cell death [4,5]. Nevertheless, in some cases elevation of cellular ROS in cancer cell lines appeared insufficient to induce cell death and other cellular actions such as depletion of glutathione that was found affected [5]. In this work, we explored the potential inhibition of proteasome by PL 1 and some of its analogs. The proteasome is considered as the central hub of nonlysosomal cellular proteolysis and its inhibition leads to a large variety of cellular responses such a cell cycle arrest and increase of proapoptotic factors and tumor suppressors [21]. Our results on HeLa cell line with compound 1 suggest that the selective inhibition of iCP may also partly contribute to its observed cellular effects cancer lines. It will be also probably the case for the analog 4 despite its diminished toxicity efficacy by a factor of 5 .

\section{Conclusion}

This work gives a direct evidence for the inhibition of iCP, but not of $\mathrm{CCP}$, by piperlongumine $\mathbf{1}$ and two analogs. Upregulation of immunoproteasome has been observed in several cancers suggesting that immunoproteasome plays an important role in cancer cell survival [7]. Moreover, targeting selectively iCP may be essential in the treatment of several diseases [22]. The lack of selectivity of bortezomib and carfilzomib against $\mathrm{cCP}$ and iCP leads to the undesired inhibition of CCP in normal cells and in part explain the side effects and resistance observed during treatments of multiple myeloma with these drugs [23,24]. Selective inhibitors of immunoproteasome are thought to lead to clinical benefits in the treatment of several diseases such as neurodegenerative diseases, inflammation, autoimmune disorders and certain types of cancer [25]. These expected benefits explain the current focus on selective immunoproteasome inhibitors. For example, the inhibition of the $\beta 5 \mathrm{i}$ subunit of iCP was found to lead benefit for the treatment of arthritis and colorectal carcinoma [26,27]. If numerous potent proteasome inhibitors have been obtained, selective inhibitors of immunoproteasome are far less numerous. Only one (compound KZR-616) that is an analog of the epoxyketone ONX094 is in clinical trial. This work demonstrates that the structural characteristics of piperlongumine A may inspire the development of original inhibitors of immunoproteasome acting through either a reversible or an irreversible mechanism. Piperlongumine analogs displaying an improved iCP inhibition may lead to therapeutical treatments involving the modulation of several targets (polypharmacolgy) since piperlongumine is known to increase reactive oxygen species and apoptotic cell death in cancer cells.

\section{Conflicts of interest}

All authors declare no conflict of interest.

\section{Acknowledgments}

We thank FASPEP (Brazil) for grant fellowship for J. N. and Ministère de l'Enseignement Supérieur et de la Recherche (France) for financial support of E. B. We thank Prof. J. Vidal (University of Rennes I) for fruitful discussions. Supports from the Centre National de la Recherche Scientifique and University Pierre et Marie Curie (UPMC-Sorbonne Universités) were greatly appreciated.

\section{References}

[1] D.P. Bezerra, C. Pessoa, M.O. de Moraes, N. Saker-Neto, E.R. Silveira, L.V. CostaLotufo, Overview of the therapeutic potential of piplartine (piperlongumine), Eur. J. Pharmaceut. Sci. 48 (2013) 453-463.

[2] A. Glasauer, N.S. Chandel, Targeting antioxidants for cancer therapy, Biochem. Pharmacol. 92 (2014) 90-101.

[3] M. Valli, W. Altei, R.N. dos Santos, E.C. de Lucca Jr. M.A. Dessoy, R.M. Pioli, F. Cotinguiba, X. Cachet, M. Furlan, L.C. Dias, A.D. Andricopulo, V.S. Bolzani, Synthetic analogue of the natural product piperlongumine as a potent inhibitor of breast cancer cell line migration, J. Braz. Chem. Soc. 28 (2017) 475-484.

[4] L. Raj, T. Ide, A.U. Gurkar, M. Foley, M. Schenone, X. Li, N.J. Tolliday, T.R. Golub, S.A. Carr, A.F. Shamji, A.M. Stern, A. Mandinova, S.L. Schreiber, S.W. Lee, Selective killing of cancer cells by a small molecule targeting the stress response to ROS, Nature 475 (2011) 231-234.

[5] D.J. Adams, M. Dai, G. Pellegrino, B.K. Wagner, A.M. Stern, A.F. Shamji, S.L. Schreiber, Synthesis, cellular evaluation, and mechanism of action of piperlongumine analogs, Proc. Natl. Acad. Sci. U. S. A. 109 (2012) $15115-15120$

[6] M. Jarvius, M. Fryknas, P. D'Arcy, C. Sun, L. Rickardson, J. Gullbo, C. Haglund, 
P. Nygren, S. Linder, R. Larsson, Piperlongumine induces inhibition of the ubiquitin-proteasome system in cancer cells, Biochem. Biophys. Res. Commun. 431 (2013) 117-123.

[7] P.M. Cromm, C.M. Crews, The proteasome in modern drug discovery: second life of a highly valuable drug target, ACS Cent. Sci. 3 (2017) 830-838.

[8] P. Sledz, W. Baumeister, Structure-driven developments of 265 proteasome inhibitors, Annu. Rev. Pharmacol. Toxicol. 56 (2016) 191-209.

[9] G.A. Collins, A.L. Goldberg, The logic of the 26S proteasome, Cell 169 (2017) $792-806$.

[10] A. Desvergne, E. Genin, X. Marechal, N. Gallastegui, L. Dufau, N. Richy, M. Groll, J. Vidal, M. Reboud-Ravaux, Dimerized linear mimics of a natural cyclopeptide (TMC-95A) are potent noncovalent inhibitors of the eukaryotic 20S proteasome, J. Med. Chem. 56 (2013) 3367-3378.

[11] N. Gallastegui, P. Beck, M. Arciniega, R. Huber, S. Hillebrand, M. Groll, Hydroxyureas as noncovalent proteasome inhibitors, Angew. Chem., Int. Ed. Engl. 51 (2012) 247-249.

[12] E. Genin, M. Reboud-Ravaux, J. Vidal, Proteasome inhibitors: recent advances and new perspectives in medicinal chemistry, Curr. Top. Med. Chem. 10 (2010) 232-256

[13] X. Marechal, E. Genin, L. Oin, O. Sperandio, M. Montes, N. Basse, N. Richy, M.A. Miteva, M. Reboud-Ravaux, J. Vidal, B.O. Villoutreix, 1,2,4-Oxadiazoles identified by virtual screening and their non-covalent inhibition of the human 20S proteasome, Curr. Med. Chem. 20 (2013) 2351-2362.

[14] J. Adams, M. Kauffman, Development of the proteasome inhibitor Velcade (bortezomib), Canc. Invest. 22 (2004) 304-311.

[15] J.J. Shah, E.A. Stadtmauer, R. Abonour, A.D. Cohen, W.I. Bensinger, C. Gasparetto, J.L. Kaufman, S. Lentzsch, D.T. Vogl, C.L. Gomes, N. Pascucci, D.D. Smith, R.Z. Orlowski, B.G. Durie, Carfilzomib, pomalidomide, and dexamethasone for relapsed or refractory myeloma, Blood 126 (2015) 2284-2290.

[16] P. Moreau, T. Masszi, N. Grzasko, N.J. Bahlis, M. Hansson, L. Pour, I. Sandhu, P. Ganly, B.W. Baker, S.R. Jackson, A.M. Stoppa, D.R. Simpson, P. Gimsing, A. Palumbo, L. Garderet, M. Cavo, S. Kumar, C. Touzeau, F.K. Buadi, J.P. Laubach, D.T. Berg, J. Lin, A. Di Bacco, A.M. Hui, H. van de Velde, P.G. Richardson, T.M.S. Group, Oral ixazomib, lenalidomide, and dexamethasone for multiple myeloma, N. Engl. J. Med. 374 (2016) 1621-1634.

[17] J. Clerc, B.I. Florea, M. Kraus, M. Groll, R. Huber, A.S. Bachmann, R. Dudler, C. Driessen, H.S. Overkleeft, M. Kaiser, Syringolin A selectively labels the $20 \mathrm{~S}$ proteasome in murine EL4 and wild-type and bortezomib-adapted leukaemic cell lines, Chembiochem 10 (2009) 2638-2643.

[18] D.S. Hewings, J.A. Flygare, I.E. Wertz, M. Bogyo, Activity-based probes for the multicatalytic proteasome, FEBS J. 284 (2017) 1540-1554.

[19] M. Halasi, M. Wang, T.S. Chavan, V. Gaponenko, N. Hay, A.L. Gartel, ROS inhibitor N-acetyl-L-cysteine antagonizes the activity of proteasome inhibitors, Biochem. J. 454 (2013) 201-208.

[20] M. Groettrup, C.J. Kirk, M. Basler, Proteasomes in immune cells: more than peptide producers? Nat. Rev. Immunol. 10 (2010) 73-78.

[21] A. Ciechanover, J.A. DiGiuseppe, B. Bercovich, A. Orian, J.D. Richter A.L. Schwartz, G.M. Brodeur, Degradation of nuclear oncoproteins by the ubiquitin system in vitro, Proc. Natl. Acad. Sci. U. S. A. 88 (1991) 139-143.

[22] A.V. Singh, M. Bandi, M.A. Aujay, C.J. Kirk, D.E. Hark, N. Raje, D. Chauhan, K.C. Anderson, PR-924, a selective inhibitor of the immunoproteasome subunit LMP-7, blocks multiple myeloma cell growth both in vitro and in vivo, Br. J. Haematol. 152 (2011) 155-163.

[23] D. Niewerth, G. Jansen, Y.G. Assaraf, S. Zweegman, G.J. Kaspers, J. Cloos, Molecular basis of resistance to proteasome inhibitors in hematological malignancies, Drug Resist. Updates 18 (2015) 18-35.

[24] E.E. Manasanch, R.Z. Orlowski, Proteasome inhibitors in cancer therapy, Nat. Rev. Clin. Oncol. 14 (2017) 417-433.

[25] G. Kaur, S. Batra, Emerging role of immunoproteasomes in pathophysiology, Immunol. Cell Biol. 94 (2016) 812-820.

[26] J. Koerner, T. Brunner, M. Groettrup, Inhibition and deficiency of the immunoproteasome subunit LMP7 suppress the development and progression of colorectal carcinoma in mice, Oncotarget 8 (2017) 50873-50888.

[27] T. Muchamuel, M. Basler, M.A. Aujay, E. Suzuki, K.W. Kalim, C. Lauer, C. Sylvain, E.R. Ring, J. Shields, J. Jiang, P. Shwonek, F. Parlati, S.D. Demo, M.K. Bennett, C.J. Kirk, M. Groettrup, A selective inhibitor of the immunoproteasome subunit LMP7 blocks cytokine production and attenuates progression of experimental arthritis, Nat. Med. 15 (2009) 781-787. 